\title{
14 Complexity of Gender and Age in Precarious Lives: Malian Men, Women, and Girls in Communities of Blind Beggars in Senegal
}

\author{
Codou Bop ${ }^{1}$ and Thanh-Dam Truong ${ }^{2}$
}

\begin{abstract}
$^{3}$
This chapter provides a perspective on the migration of communities of blind beggars from Mali to Dakar, Senegal. Migration for begging across borders as a way of making a living adopted by persons affected by river blindness involves being guided by non-blind guides - usually a girl or young woman who can be a relative or acquaintance. The patterns of movement are generally seasonal and circular and are based on a variety of social arrangements for guiding, including a modification of 'child fostering' as a tradition, biological kinship and marriage, and employment. Each type of arrangement delineates specific obligations and entitlements between the guides and the beggar according to the relationship involved: parent, guardian, spouse, or employer. The last arrangement applies especially to girls and women who migrate on their own account in search of other types of work but end up as guides. Social justice strategies that address the individual rights of young migrants from Mali to Senegal have yet to recognize the existence of this group of female guides. Understanding the experiences of the migrant blind beggars from the perspective of multiple conditions of 'disability' may help towards an appreciation of how mutual dependency based on gender and age can be interwoven into layers of culturally defined inter-generational obligations, for which social justice strategies built only on the idea of the individual rights of women or children may not necessarily be appropriate.
\end{abstract}

Keywords: Circular migration, Senegal, Mali, West Africa, children, gender, generation, begging, livelihood, disability, river blindness, social justice.

\subsection{Introduction}

A large body of literature on migration in West Africa tells of the complexity of migratory movements at lo-

1 Codou Bop is a researcher and activist on women's human rights and the coordinator of Groupe de Recherche Femmes et Lois au Sénégal (GREFELS) based in Dakar, Sénégal.

2 Thanh-Dam Truong is Associate Professor at the International Institute of Social Studies, Erasmus University Rotterdam, The Netherlands.

3 This chapter draws on the results of a broader study funded by IDRC, project number I0489I-0oI, and entitled: "Femmes, Migrations et Lois au Mali et Sénégal" (Women, Migrations and the Law in Mali and Senegal) implemented by the Research Group on Women and Laws in Senegal (Groupe de Recherche Femmes et Lois au Sénégal). The members of the research team are: Codou Bop, Fanta Cissé, Fatou Binetou Dramé, Aissa Haidara Touré, Ndeye Sokhna Guèye, and Cheikh Ibrahima Niang. cal, national, and international levels, and of its especial role in sustaining and expanding people's livelihoods (Adepoju 2004; De Haan/Brock/Coulibaly 2002). With some exceptions (Sy I99I; Findley I99I; Brockerhoff/Eu 1993; Gondola 1997a, 1997b), this body of literature generally emphasizes the experience of the male migrants. In recent years some attention has been given to the autonomous migration of women and people under eighteen years of age (Findley I99I; Bocquier/Traore 2000). Within this subset of the migration literature, much attention has been given to practices of child trafficking and fosterage for economic exploitation (Kielland/Tovo 2006), and to the migration of children as soldiers in the context of armed conflicts (Machel 1996). Analyses of child labour migration that place emphasis on 'gender' distinguish between the types of work that boys and girls do - domestic work and sexual services for young girls and agricultural work and fishery for young boys (UNICEF 2002; Truong 2005; de Lange 2007). The 
relationship between gender, child migration, and 'streetism' as a mode of life has also recently been looked into. This has demonstrated not only that there are multiple causes behind children's moving to the street to make a living, pointing to the need to treat 'gender' and 'age' as power relations rather than merely ascriptive characteristics (Awumbila/ArdayfioSchandorf 2008), but also that the term 'street children', being associated with delinquent behaviour, can have a stigmatizing effect. Caution should be exercised to avoid further discrimination against girls and young women, and instead the causes related to structural inequality should be examined (Eshia 20IO).

This chapter provides a perspective on the situation faced by Malian girls and young women who migrate from rural and peri-urban areas to Dakar, the Senegalese capital city, to guide beggars who are relatives or acquaintances affected by Onchocerciasis and Trachoma. ${ }^{4}$ People affected by these insidious and non-fatal diseases must endure lifelong suffering and grave socio-economic problems as regards their identity and relations with family and community. Begging is one way of earning a living while maintaining a sense of self-worth and dignity, but requires the crucial assistance of a guide, especially when the activity is conducted across borders. The activity can be lucrative, but beggars and their communities must endure harsh conditions when on the move and as transient migrants.

As section I4.2 shows, migration in West Africa is showing trends of increased feminization (a higher proportion of women) and precociousness or increasingly younger chronological age. The perspective on the migration of beggars and their guides presented in section I4.3 is based on the findings of multi-sited research in Mali and Senegal. The aim is to provide insights into the prevailing practices of migration,

4 Commonly known as river blindness, Onchocerciasis is caused by Onchocerca volvulus, which is transmitted to humans by the bite of infected black flies which breed in fast-flowing streams and rivers; it often blinds people, as well as causing a debilitating skin disease. Onchocerciasis can be cured by a drug called Mectizan which kills the parasite's larvae in the human body, preventing blindness and transmission of the disease to others (Remme 1995). Trachoma, also known as river blindness, is the result of infection of the eye with Chlamydia trachomatis. Infection spreads from person to person, and is frequently passed from child to child and from child to mother, especially where there is a shortage of water, many flies, and crowded living conditions (Mufioz/West I997). their gender and age dimensions, and the layers of vulnerability experienced by women and girls as guides. Migrating to Dakar in the dry season is based on interrelated considerations, such as Ramadan - a holiday linked with the giving of alms and demonstrating Muslim piety - and the fact that the spaces they occupy in the city are not flooded, and so are habitable even on the streets. The preference for girls rather than boys as guides is both social and economic. Five types of social arrangements applicable to girls and young women who guide the blind are identified, demonstrating the key relationships that shape their migration and the scope for them to assert control over their own life.

In section I4.4, the legal and institutional frameworks for the protection of child migrants in Mali and Senegal are discussed, demonstrating a misfit between the social constructions of 'children' and 'gender' upon which current migration and human trafficking policies in the region are based, and the reality as lived by blind beggars and their guides. This calls for a re-evaluation of the ideal notion of 'childhood', the interpretation of 'gender' in migration, and the dominant notion of 'disability' as physical or mental impairment.

Understanding the situation faced by the blind beggars from the perspective of multiple conditions of 'disability', as well as the situation faced by their female guides from a perspective of multiple-layered vulnerability, can help identify the specific aspects of gender as an adaptive structure in a web of culturally defined intergenerational mutual dependence.

\subsection{Contextualizing the Migration of Men, Women, and Children in Senegal and Mali}

Well before West Africa was colonized by the European powers, migration had taken diverse patterns, driven by a multiplicity of causes, such as long-distance trade and search for pastures and work (Cordell/Gregory/Piché 1996). Subregional migration, intensified under colonization owing to urbanization, the growth of administrative and industrial centres, and plantation agriculture, continues today with little regard for post-colonial borders (Colvin I98I; Diop 2008). In the last few decades, rural-urban migration patterns have changed from seasonal and circular movements by individual men to more permanent migrations, frequently involving part of or the entire family unit (Riddell 1980). These migrations, studied 
by Findley (1989, I99I, 1997), Sy (199I), Bâ (1996), and Lambert (2007), are progressively more feminized, with women increasingly migrating autonomously. This may be a response to the combined effects of drought and the structural adjustment policies implemented since 198I, both of which have led to a worsening of living conditions in rural areas (Toulmin/ Guèye 2003; Truong 2006); it is also possible that women left rural areas to escape not only from poverty but also from dependency on their men. Migration by unmarried women can now arguably be viewed more as an individual endeavour than a family strategy (Bocquier/Traoré 2000; Lesclingand 2004).

The presence of Malians in Senegal has been fostered both by a common political history and by administration as a unified territory during the colonial period. ${ }^{5}$ The Senegalese Navetanat system of seasonal labour ${ }^{6}$ was also a factor. Navetanat is characterized by a massive short-term migration of young people - generally from the areas where subsistence agriculture predominates - for intensive and temporary work on commercial groundnut farms (David 1980). The system was consolidated by the close ties with the areas of origin through social and financial remittances. For young people the Navetanat was often a means to escape the power of, and abuse by, the elders that the colonial authorities ignored (Bourgeot I977). The Navetanat developed rapidly following the expansion of trade in agricultural commodities until the economic crisis of the I970s, declining only through the combined effect of drought and falling global prices, particularly for groundnuts (Ndiaye 2OI2). Migrants seeking longer-term and more remunerative temporary urban employment gradually abandoned the system (Gubert 2007).

At the peak of the Navetanat system in the I96os and I970s, many migrants originated in the Kayes region in the western part of Mali, bordering Senegal and Mauritania. Their movement was facilitated by the Kayes-Dakar rail connection as well as by social connections, with two-way movements being so common that they did not, and do not, carry the meaning

5 The Malian Federation was founded on 4 April I959, uniting Senegal and the Sudanese Republic (formerly French Sudan), and became entirely self-governing when it gained independence from France on 20 June 1960. The federation collapsed shortly after independence, on 20 August 1960, when Senegal withdrew, due to political disagreements. The Sudanese Republic was renamed the Republic of Mali on 22 September 1960. See Foltz (1965).

6 Navet means rainy season in Wolof. of crossing a national border for the people involved (Fall 2003). Today, long-lasting or permanent settlements by Malians in the city of Dakar can be found in communities specializing in particular economic activities. These communities, particularly those formed from people of Soninke origin from the valley of the upper Senegal river and from the Bambaras of the Kayes region, have mostly traded cola nuts (especially the men) and dyed fabrics and food (especially the women) and settled in Dakar, Thies, Saint-Louis, and Mbour. The first and second generations of migrants act as hosts to the latecomers (Fall 2003). Today, internal and cross-border migrations in search for work - whether seen from the perspective of a strategy to diversify household livelihoods or as a path to 'modernity' - are showing signs of being undertaken more and more by those who are increasingly younger in chronological age (ILO 2007; BIT/LUTRENA 2007; Moens/Zeitlin/Bop/Rokhaya 2004).

\subsection{Circular Migrations for Begging}

\subsubsection{Research Methodology}

This study is among the first multi-sited research projects on the migration of adult blind beggars and their female guides. Its results are to be considered as preliminary. Its aim is to raise new questions for research on the links between disability, gender, and age in migration and the appropriateness of human trafficking and children's rights as a policy field in West Africa. In Mali three regions (Bamako, Koulikoro, and Kayes) were chosen as research sites with the help of resource persons, including (ex)-migrants and officials. All three regions are known to have been affected by river blindness. In addition, Kayes City is known to be the main transit point for Malian children before they leave for Senegal. Interviews (with bilingual Bambara-Wolof translation) were conducted with twenty-two blind beggars and forty-one adolescent returnees from Senegal who were being assisted by a civil society organization for reintegration. In addition, interviews were attempted with seventeen persons working in a wide range of institutions active in the migration field (specialized agencies of the United Nations, non-governmental organizations, and women's organizations), but they were unaware of the existence of female guides within the flow of blind beggars across the border.

A key message that emerged from interviews with Malian beggars at the different research sites con- 
Figure 14.1: Map of Mali with indication of the research sites (Bamako, Koulikoro, Kayes). Source: United Nations (2012; permission granted 12 November 2012).

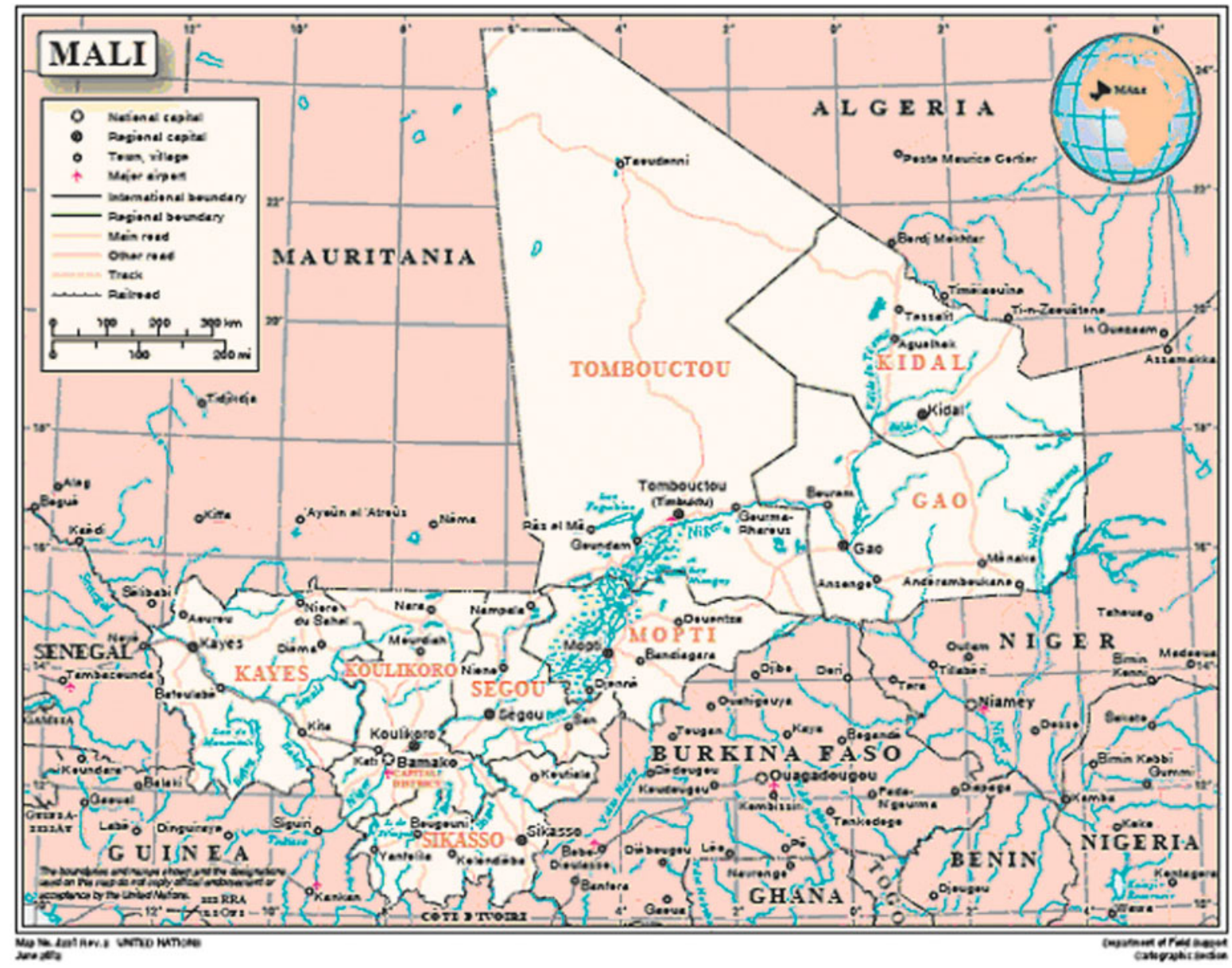

cerned economic motivation, namely the belief that Senegalese people are more pious and make higher donations than Malians, and that girls inspire pity and are more likely to bring in large donations. Socially, girls are also preferred as guides because they are thought to be more 'courageous' and able to accept the strenuousness of their occupation without complaining. Further, the adolescent returnees provided insights on the trajectories of migration and modes of adaptation in transit and destination, highlighting how border porosity, the railroad, and new developments in public transport facilitated their journey between Mali and Senegal.

Being both the main destination and accessible for research, Dakar was chosen as a research site on the receiving end. Within Dakar, research sites were the Dakar-Bamako train station, the mosque on Fleurus Street (Grand-Yoff), and Castor, all areas that host communities of blind beggars from Mali. Because the use of the survey method to obtain disaggregated socio-demographic information about the target population was unsuccessful due to non-cooperation, this information was gathered during one-to-one and semi-structured interviews.

It should be noted that Senegalese law forbids begging, and a few months before the study began there were several police and municipal raids. Beggars were thus anxious to avoid attention from the authorities, fearing forced repatriation to Mali if their identity was revealed. The ethics of research also had to be taken into consideration, because normally children should only be interviewed in the presence of their parents or guardians, or with the latter's authorization. Where this was impossible, a retired female Malian teacher who has lived in Senegal for many years was hired as a facilitator and translator. The fact that she was an elderly person with a respected position also helped temper the concerns of the blind beggars. The use of "la parenté à plaisanterie" greatly helped improve the relationship between the researchers and the participants. 
Figure 14.2: Map of the Communes d'Arrondissement of Dakar Department with indication of research sites: Plateau; Grand-Yoff; Castor; Liberté; Grand Dakar. Source: Wikimedia Commons.

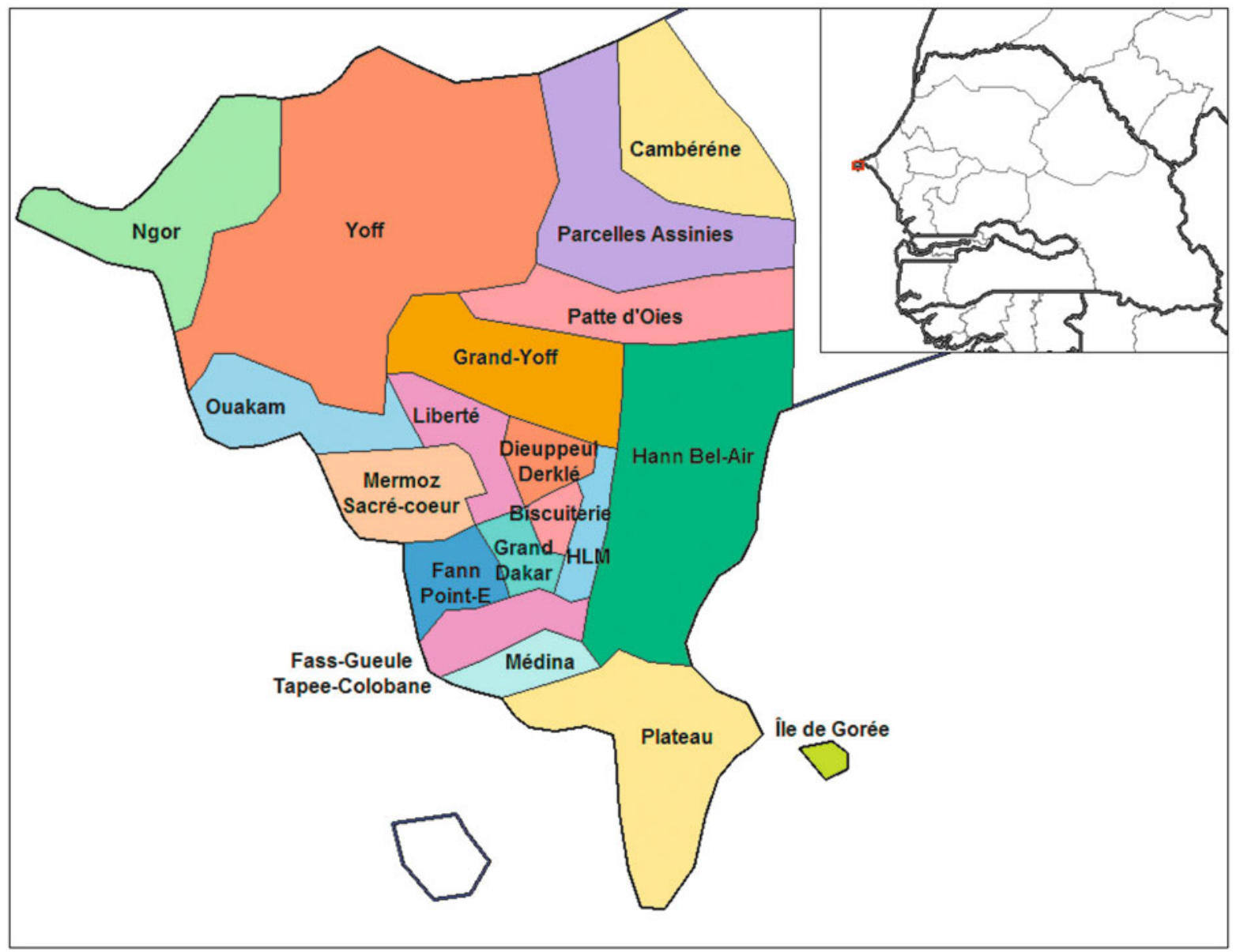

The interviewers placed the blind beggars in the position of 'resource persons', together with a few people in the Senegalese communities. Through this technique, information could be gathered from the migrant young women and girls as research subjects, as well as from beggars as migrants who also shared their own personal experiences. In total, twenty-five male and one female blind beggars (between 24 and 70 years of age) and fifteen female guides (between the ages of IO and 26) were interviewed, some in the presence of their father, mother, husband, or guard-

7 This social practice, known as a kind of joking relationship, is unique in West Africa. Known as Sinankunya in Mali, Rakiré in Mossi of Burkina Faso, Toukpê in Ivory Coast, and $\mathrm{Kal}$ in Wolof Senegal, the practice allows, and even requires, members of the same kin group and ethnic groups to mock or insult without consequence. The practice is a means of easing tension and reinforcing alliances between clans whose members are obliged to help each other (Labouret 1929). ian. Age was found to be an arbitrary measure, given that many children began guiding the blind when under ten in their home country and now practise it as cross-border migrants.

The semi-structured questionnaire was designed to elucidate, from respondent biographies, the process of becoming migrant beggars or guides, their trajectories of migration, and their means of coping in Dakar. This provided an opportunity for the respondents to relate in great detail their migration experiences, and through these the researchers were able to gain an indepth understanding of the social meanings of disability and the notion of masculinity as the provider. This examination of the migration of children and young people within a social enclave of poverty shows the significance of gender and intergenerational mutual dependency, and thus may help to raise more awareness about the links between gender, disability, migration, and life choices. 


\subsubsection{Multiple Conditions of Disability and Migration for Begging as a Livelihood}

The medical anthropologist Kaplan-Myrth (200I) suggests that where the conditions of everyday life are disabling, as in the case of rural Mali, ${ }^{8}$ the modes of coping adopted by people suffering from river blindness should be seen from the perspective of multiple and interwoven disabilities. This perspective involves a shift away from the logic of disability prevention that sees ignorance of the origin of river blindness as the main cause. It focuses on how people deal with the disease as a given, something that diminishes their capabilities but not necessarily their social roles and obligations. When prevention programmes do not reach them, they continue to cope with their everyday life and their insidious illness.

In Mali, most of the health care centres that have treatment/medicine to offer for river blindness are located in Bamako, the capital, or in towns and villages along the Niger river. There are also programmes for prevention (eye examination, specialized procedures, distribution of drugs, provision of supplies and information) in health posts in villages throughout the country. However, poor accessibility due to poor infrastructure, lack of motivation, and poor organization preponderate in many infected areas (Thylefors 1985; Sommer 1989). This reduces prevention and, as Kaplan-Myrth (200I) noted, in remote areas people suffering from river blindness simply refer to the illness as a 'disabling fact of life', 'the worst possible fate', 'the will of Allah', and as a destiny that must be coped with. Since blindness diminishes their ability to work in their fields and homesteads, begging is considered an acceptable means of survival, though many undertake other manual tasks for a living as much as possible, such as spinning cotton rope, shelling peanuts, and weaving plastic to make cots and chairs (Kaplan-Myrth 200I: 99-I02). This perspective resonates with the findings of this research, with one additional feature: crossing borders to beg requires the sustained support of a guide and a caretaker of daily needs in an alien environment.

Interviews conducted in Mali revealed that the majority of women and girls and the blind beggars they guide come from remote rural areas in the Kayes region (Bafing, Mahina, Kita, and Brigo towards Kar-

8 By 'disabling', Kaplan-Myrth refers to the lack of basic infrastructure such as access to clean water, adequate housing, roads, electricity, health care, and education, combined with malnutrition and infectious disease. amokola). The others come from Koulikoro, Segou, and other rural areas. Many of these villages are close to one of two dams, the Manantali in the Kayes region and the Tienfala in the Koulikoro region, with the proximity of the dams linked to river blindness. Begging across the border, which seems to have begun around the 2000 s or possibly before, involves circular and seasonal migration. They usually travel during Ramadan and stay through the dry season. This pattern is closely related to the availability of housing and the living conditions in the street. During the rainy seasons, the areas they occupy are flooded and become uninhabitable.

The most common means of transport is the Bamako-Dakar train. Blind beggars are often allowed to travel by rail for free, being seen as destitute. The girls who accompany them sit between the cars in front of the toilets, a location considered dangerous by the railroad employees and ignored by the ticket collectors because of the risk of accident. As the railways become increasingly privatized, travelling by bus, truck, or canoe for some parts of the trip, or walking for some stretches, have become more common. Such trips do not happen in one go. Beggars generally stay (in transit) in the big cities, especially Bamako and Kayes. While in transit, children and young people may take up small jobs such as load carriers or shoe polishers to earn their fare. They then move from Kayes, hundreds at a time, towards Kidira, Bakel, Tambacounda, Goudiri, or Diawara. Some beggars and their guides travel on foot to Kayes. Once in Kayes they go to Berola in the Kenieba circle and cross the river which forms the border between Mali and Senegal in order to get to Sayanssou; from there they continue to Kedougou. In Senegal, for those who decide to go on to Banjul in The Gambia, the transit cities are Kidira, Tambacounda, Kaolack, Thies, and Dakar.

Senegal is attractive for beggars from neighbouring countries partly because the standard of living is higher, but mainly because the Senegalese are reputed among Malians to be pious and to diligently honour the Islamic requirement to give alms. A resource person in Mali explained:

A beggar who is a head of his household may get to hear from other Malian beggars telling of their experience in Senegal and of how much money can be made and may decide to travel with his family.

Interviewees, including resource persons and the girls themselves, explained that at the moment of departure the girls becoming guides were happy to be doing so because they thought they would be able to shop for their marriage trousseau. Their parents also prom- 
ised them presents and explained that their father would be able to build a house for the family. According to the imam of the mosque at Fleurus Street in Dakar, who is a Malian:

Begging is a job for disabled Malians in Senegal. It's a lucrative business, as shown by their large communities. Although some end up doing this all their lives, for others it is a necessary but short-term means of acquiring funds for various projects - such as starting a business, buying supplies, buying and/or building a property. Several beggars and adult guides have managed to own a house from what was earned by begging.

Migrating to beg as a means of livelihood has also been associated with declining community support in the home villages. A 44-year-old blind male beggar explains:

We have to feed and clothe our children. The community does not do anything for the children of the blind and each blind beggar must look after his children, so that they can look after themselves in the future. I want to buy a house for my family and have been sending money to my brother, but the amount is not yet sufficient.

The way in which beggars make their living is not really offensive to the Senegalese population, even when practised by children. Interviewees related that earnings from begging can be twice or three times as high in Senegal as in Mali. In Mali, daily earnings may be between 300 and 3,000 Communauté Française d'Afrique (CFA) francs, equivalent to less than US\$I to 6. In Dakar the daily amount can be as high as Io 000 to 20000 CFA francs (US\$20 to 40). These earnings are used in various ways: remittances to family members who stay behind in Mali; basic living costs of the beggar and his/her family in Senegal; and purchasing personal effects, cereals, and other foodstuffs to be taken back to the village upon the beggar's return home.

\subsubsection{Gender and Age in Guiding and Living Conditions}

According to adult respondents in a village in Mali, once a daughter is 'mentally competent' to guide her blind father, she is required to accompany him. Boys generally refuse to guide their blind parents when they reach a certain age (between nine and twelve) because of shame. When they join the flow of migrant beggars, they beg for themselves. Some beggars keep their own daughters in Mali, and once in Senegal they hire girls of the same ethnic group to guide them.

Five main types of arrangements for the girl children and women as guides were discerned from the interviews. The first type involves the girl who serves as guide for her biological father or mother who is blind. In the words of a thirteen-year-old girl:

I came here with my blind father six months ago. He first went to Bamako with my mother to beg. My two older brothers work in the fields. But my younger brother fell ill and my mother returned to take care of him. So my father took me with him [on his next trip]. I miss my mother and brothers. But my father says that we will return at the beginning of the rainy season and we can bring them money and lots of things. Here people give us food and clothing and we sleep in front of the mosque.

A sixteen-year-old girl told the following story:

My father has passed away. I am the second child. My elder sister is married and looks after my younger brother. My blind mother and I came from a rural area and I guide her to beg. My mother heard from other people that earnings during one day here [in Dakar] can be as much as earnings during one month of begging where we come from. My mother used her savings and with the help of her brother we took the train to come here.

A blind male beggar, forty years of age, explained how his daughter became his guide:

My wife has our baby on her back. I feel sorry for her. Guiding me is very tiring for her because we have to walk a lot. So I ask my little girl to guide me and let my wife beg on one spot. When daughter guides me I notice that my earning is higher than when I ask one of the girls from our community to guide me. These girls scam us because they practise the tontine and save for a house upon their return to Mali.

The second type involves girls who were required by their parents to travel to Senegal to guide a blind beggar in exchange for financial or material resources for the parents. The beggar may not be related to the girl and her family, but comes from the same village in Mali. The girl may be the niece or daughter of a friend or neighbour of the beggar. The arrangement between the girl's parents and the beggar is called 'lending'. In the words of a ten-year old girl:

My father has 'loaned' me to my uncle. My father made the decision and my uncle asked me if I wanted to come along with him. I knew what I have to do once in Dakar and I agreed. My uncle paid my transport. We came here four months ago and I have no contact with my family since. I have no idea if he has sent money to my parents.

The third type involves those who were married to the beggar they guide before leaving Mali. Resource persons also told us about some women being married to blind beggars under the custom of levirate, ${ }^{9}$ 
sometimes by force - especially the younger ones. A forty-four-year-old blind beggar on Fleurus Street explained:

My young wife guides me. My friend, Sékou Konaté, gave away his daughter to me in marriage. She is my fifth wife. The others have left me because I fell ill. I have been coming here to beg since 2003. I had been saving to buy salt for trade. Two years ago, I was able to buy two tonnes of salt. I was counting on buying a grinding machine with the money earned from selling the salt. But the customs officer demanded a sum of 200000 CFA francs (US\$400) for clearance. I did not have the money so I lost my merchandise. If it were not for this customs officer I would have stopped begging and returned home with a business.

The fourth type involves those who are 'rented out' on a daily basis by their mothers (also blind beggars) to a blind male beggar with whom they share the same sites. Being old, widowed, or divorced, these women ${ }^{10}$ earn through their own begging in addition to the services provided by their girl children to the adult male beggars; the children do not receive any compensation due to the fact that the agreement is made between adults. A seventy-year-old blind beggar explained:

There are blind beggars who come without their wives or children. They hire girls to guide them and they divide the earnings in half at the end of the day with the girl's father or mother. Often the girls themselves also come to the beggars looking for work.

The fifth type involves young women who independently migrated to Senegal in search for work, often as housemaids, but could not find work and have ended up becoming guides for beggars. Unrelated to the beggars through kinship, they work for earnings in a strictly economic relationship without the intervention of a parent.

A twenty-year-old female guide explained:

I have lost both of my parents and I live with my grandmother. My grandmother convinced me to go with her to Senegal because she had been there and knows the place. I guide blind beggars who need me and we share the earnings at the end of the day. It is a professional relationship and I keep my share of the earnings. People give us clothes here and I don't have to buy them. I want to save money to buy merchandise and sell it upon our return to Mali. That way I don't have to guide beggars any more.

9 Levirate marriage is a marriage in which a man takes over the widow of a family member.

10 These were Senegalese women who live and beg in the same area as their Malian counterparts.
Those who provided guiding services in return for a share of earnings admitted that begging could be lucrative - particularly when their beggar employers paid for their meals. Resource persons in Mali and Dakar confirmed that some of these young women, as returnees, were able to buy goods (televisions, furniture, foodstuffs) to take back to their home towns or villages. Some have managed to use their savings to buy land or set up an income-generating activity in their home country. In Dakar, there were also cases in which the companionship between these independent women and the beggars has led to a relationship of affection and love, and even marriage. In these cases the pair continues the same arrangement for their work, though the guides can be more independent since they have become indispensable partners for the beggars. Some can negotiate a position as an equal partner, gain autonomy, and achieve a position of authority vis-à-vis their blind husbands. ${ }^{11}$

In Dakar, the main problems the beggars encounter are housing and personal security, though newly arrived people fairly quickly integrate into migrant begging communities. Those who do not immediately find a place to stay often share the shelter of another couple until an alternative can be found. The lucky ones are those who can find a tiny room built from cardboard and sheet metal in Grand-Yoff, Hann village, or Castor. These housing arrangements are privately owned and managed by the local population and rented to the beggars. They are situated close to water discharge canals. On Valmy Street, a part of the begging community lives in a run-down building, paying on average Io 000 CFA francs (US\$20) per month; but the majority sleep in the street 'en famille' around the mosque in Fleurus Street or the mosque of Grand Dakar or inside the Dakar train station. A Malian women trader in the Malian market at the Dakar train station describes these shelters as follows:

The girls and the beggars live in rooms made of wood, metal sheets, or rice bags or plastic sheets with many holes. The rooms are overcrowded with adults and children, bags of clothes, and other belongings. To sleep, they place mats on the ground and fold them up during the day. The building belonging to the Cité des Eaux near Bignona in Grand-Yoff has many rooms in a row,

11 The researchers once witnessed a marital dispute over the amount of money obtained from selling a donated piece of meat. The husband complained that the amount appeared too low and was met with rather defensive behaviour on the part of his wife. The young wife had to be calmed down by neighbours to prevent escalation of the dispute. 
with narrow doors and without windows. The rooms have quite high ceilings but there is no electricity or water. Apart from these, there are even more dicey shelters, with doors that cannot be closed properly, or no door at all. A number of abandoned trucks are also used as shelters.

In these conditions, personal security and poor sanitation are problems. The beggars have no information about or access to banking services; they keep their money to themselves and are therefore vulnerable to attack and robbery (in their rooms or on the streets), particularly when it is publicly known that they have electronic equipment of value - radios, televisions, or mobile phones. Poor sanitation leaves the beggars and their guides vulnerable to many types of illnesses such as malaria, rheumatism, bronchitis, and skin diseases. Self-medication is practised; they buy medicines that come illegally from Mali or Nigeria and are sold nearby. In cases of serious illness they go to the local health centres or private clinics where they have to pay the full costs. A beggar complained:

To ensure that my second wife got proper care when she had problems during her pregnancy, I had to spend about 250000 CFA francs (around US\$500).

As circular migrants, girls who are guides do not have access to schools in Senegal and are kept entirely within the Malian beggars' communities. Few of them speak Wolof, the principal language in Senegal, and thus most are unable to make friends with a Senegalese. Some of those interviewed had been victims of sexual violence, or were in conflict with boys living in the neighbourhood. The young women and girls who guide the beggars spend their days walking with the beggars without a rest, and sometimes they have to go begging at night. They have little to eat, surviving on leftovers from cheap restaurants or bits of meals left by their Senegalese neighbours. Under these circumstances the burdens on the girls are more intense particularly for the biological daughters, wives through forced marriage, or 'loaned' guides. As conditions are harsh some wives have left their husbands. A wife of a beggar tells:

I guide my husband in the morning, and in the afternoon I must guide my mother. In the night I sell attiéké $e^{12}$ and fish.

In sum, young Malian female guides are frequently exposed to hazardous living conditions and strenuous work, and to all types of violence - including sexual vi-

12 Attiéké is a grain-based product processed for urban use. olence leading to unwanted pregnancy. Their ability to gain some autonomy varies, depending on their age, the type of guiding arrangement, and the relationship with the beggar which defines the term of mutual dependency: whether this is an inter-generational obligation within kinship or an employment relationship, marriage with the wife in a commanding role as the non-blind party, and so on.

\subsection{Legal and Policy Responses: The Exclusion of Young Migrant Malian Guides of Beggars}

In the context of cross-border migration today in West Africa, human trafficking, including child trafficking, becomes pertinent. There is an important legal and administrative arsenal with provisions protecting children who are victims of malpractices in crossborder migration and trafficking in West Africa and a great number of intra-regional and bilateral programmes to counter child trafficking. The most important is the United Nations Convention against Transnational Organized Crime (UNCTOC) and its Protocol to Prevent, Suppress and Punish Traffic in Persons Especially Women and Children.

The Senegalese and Malian legal and policy instruments on child trafficking follow the definition of the Protocol on human trafficking of UNCTOC (see Bop/Cissé/Touré/Niang 20I2). According to article 3 (a) of this protocol:

\footnotetext{
'Trafficking in persons' shall mean the recruitment, transportation, transfer, harbouring or receipt of persons, by means of a threat or use of force or other forms of coercion, of abduction, of fraud, of deception, of the abuse of power or of a position of vulnerability or of the giving or receiving of payments or benefits to achieve the consent of a person having control over another person, for the purpose of exploitation. Exploitation shall include, at a minimum, the exploitation of the prostitution of others or other forms of sexual exploitation, forced labour or services, slavery or practices similar to slavery, servitude or the removal of organs (UNODC 2008: 2).
}

Regarding consent, article 3 (b) states that

if a victim's consent to the intended exploitation is obtained through any improper means (threat, force, deception, coercion, giving or receiving of payments or benefits, abuse of power, position of vulnerability) then the [apparent] consent is negated and cannot be used to absolve a person from criminal responsibility. Regardless of whether their consent was obtained without use of any prohibited means, children have special legal sta- 
tus. A 'child' shall mean a person under the age of eighteen years [emphasis added] (UNODC 2008: 5).

Senegal has harmonized this Protocol with its national laws. Mali has instituted a mandatory exit visa for children, but this has not yet produced the expected results. Many children continue to move across borders by train, bus, and boat, sometimes with the full awareness of the security forces responsible for ensuring the implementation of this new measure. The only instrument between Senegal and Mali with respect to the issue of child trafficking is a bilateral agreement signed on 22 July 2004 in Dakar.

Other related international instruments include the conventions of the International Labour Office (ILO) relating to the Rights of Women and Children, the Convention on the Elimination of All Forms of Discrimination against Women (CEDAW), and the Convention on the Rights of the Child (CRC), which West African countries have signed and/or ratified. There are also regional instruments, such as the African Charter on the Rights and Welfare of the Child that came into force on 29 November 1999, and the Protocol to the African Charter on Human and Peoples' Rights on the Rights of Women adopted in Maputo in 2003. At the regional level, the Economic Community of West African States (ECOWAS), of which Senegal and Mali are members, adopted the Declaration to fight against Trafficking in Persons during the twenty-fifth Ordinary Session of Authority of Heads of State held in Dakar on 20-2I December 200I (see appendix I).

At the national level, both countries prohibit begging, although the tradition of giving alms and begging as a way of making a living are socially accepted. From the perspective of the young guides, there are discrepancies between the legal definition of 'trafficking', 'age', and 'consent' and the social reality of their migration. These discrepancies should be of concern for national institutions and organizations responsible for controlling child trafficking. Different cultural and sociological interpretations of 'childhood' are at play, especially under conditions of dire poverty. A major point of contention revolves around the question of labour exploitation and the links between practices of 'child fostering' and trafficking.

In West Africa, child fostering is an age-old practice that involves the parents' placing their child (or sometimes 'giving' the child to a childless relative) in a family, workshop, or business of a relative for apprenticeship and education. In the context of child migration today, fostering may have become a way to access child labour for which gains can be made for both parents and fosterers, given the increasing role of intermediaries who facilitate these arrangements in exchange for personal profits (Truong 2005). Research from a child-centred perspective shows that the children themselves view migration as a valuable means of improving their status and learning new skills and that they can actually benefit from its educational impact (Hashim/Thorsen 20II). Given the mixed evidence on the effects of fostering on children's well-being and education, caution should be exercised against a general demonization of the system (Serra 2009).

Furthermore, the traditional perception of the child as 'capital' to ensure the parents' old age is very much alive, not only in families but also among institutions responsible for the promotion of children's rights. A child also may not be defined solely and exclusively by chronological age. Other criteria come into play in determining the status of childhood or adulthood: capacity, strength, size, level of economic dependence, marital status, having been (or not been) subject to an initiation rite. This means that adjusting policy to local contexts may have to involve thinking about 'social age' (Clark-Kazak 2009) instead of 'chronological age'.

Thus, applying the UN definition of human trafficking has met with both local resistance (Truong 2005: 7I) and with resistance among socially engaged scholars, since a strict crime-oriented approach introduces new risks. These risks include the wrong people being punished, or the further tightening of control over the mobility of people under the age of eighteen (Busza/Castle/Diarra 2004). The puzzle regarding interaction between 'culture' and socio-economic relations, its outcome in relation to children's rights, and the question of the stage at which child labour migration can be considered as trafficking is yet to be solved. There continues to be a great deal of uncertainty, both when defining the target group and when determining the means of intervention (De Lange 2007).

Where policy concerns for child beggars are explicitly expressed, so far girls have been hardly visible to researchers. A survey conducted by the United $\mathrm{Na}$ tions Children's Fund (UNICEF) in cooperation with the project Understanding Children's Work (UCW) (2007: 2-4) on child beggars in the Dakar region asserts that boys constitute the quasi-total population of child beggars, and that ninety per cent of the child beggars in Dakar are talibés or boys who have been sent away to religious schools (daaras) for an Islamic education. ${ }^{13}$ The survey covered 7,600 child beggars, 
among whom no single girl was included, based on the belief that girls are 'marginal' in the activity of begging. Boys work up to six hours per day begging in addition to other jobs they manage to find such as carrying loads or collecting garbage. The need for special protection of the girl guides of blind beggars has to date been neither acknowledged by their families nor recognized by responsible institutions. Ironically, despite their visibility in public spaces - in the streets, at crossings, in front of filling stations and mosques -, the relevant policymakers seem unable to recognize their presence. This lack of awareness of the presence of female children in begging communities is also the case with staff at regional offices of UN agencies and at non-governmental organizations (NGOs) in Dakar whose mandate is the protection of vulnerable children.

It can be said that this invisibility in the eye of policymakers may have been reinforced by two kinds of bias. First, there is a sectoral bias in campaigns against child trafficking, leading to the targeting of particular sectors that have received public attention and dominate the global agenda. For example, cocoa production (known to employ more boys than girls) has been subject to multi-level pressure and collaborative action: consumer brands, strategic government intervention, and geographic concentration (Schrage/Ewing 2005; Ndiaye 2009). Likewise sex trafficking - believed to generate US\$7-I2 billions annually (Yen 2008: 659) and estimated at seventy per cent of all human trafficking (Adepoju 2005) - has been subject to many different types of collaborative action.

Second, there is a cognitive bias based on gender beliefs held by officials, civil society organizations, and researchers on who does what 'work' and what counts as 'work' for children. Child beggars are considered to be rare (or a small fraction of the population of children in most countries) and difficult to reach (UNICEF/UCW 2009). For the girls who guide beggars, the multiple layers of disadvantage derived from being young, female, and a member of an eco-

13 The survey method used in this study defines talibés as any child who has spent the night before the survey in a Koranic institution and has declared himself to have received religious education. It should be noted that in the past many talibés lived at home and studied at a daara in their village, while some were entrusted to marabouts (Koranic teachers) in distant villages. Today with the deterioration of rural daaras it has become common for parents to confide their boys to the care of marabouts far away and often without contact for several years. nomically insignificant group of migrants may have shut them out from the realm of policy relevance.

These biases are laid bare in the defining of 'target groups' for policy and support programmes. Under the various programmes designed to help children in difficult circumstances implemented by the UN agencies or NGOs, a number of terms have been introduced, such as street children, children in danger, trafficked children, little beggars, vulnerable children, children in vulnerable circumstances, and children in distress. None of these definitions captures the multiple conditions of vulnerability and difficulty experienced by the girls who guide blind beggars. Their difficult conditions are reinforced by a combination of power dynamics mediated through a range of social institutions (the family, child fostering for economic gain, levirate marriage) not easily captured under the category of a single target group.

In Senegal, despite the existence of many national and international institutions that support vulnerable children, most of them have as yet little knowledge of the presence of girls guiding beggars, or of the migration routes they take or their living conditions. Following an advocacy initiative, several donors agreed to fund a voluntary return migration programme involving hundreds of Malian children trafficked into Senegal, paying for the journey and providing initial moneys for income-generating activities once back in Mali. No female child was considered. There is no specific or positive discrimination policy for the families these children come from. The girls guiding beggars are also excluded from the Senegalese government's antipoverty measures, which cover children's needs and do pay special attention to the rights of the girl child in education and health.

Finally, there is little political will in either the Senegalese or Malian states to protect the rights of migrant children. Following the 2004 bilateral agreement of cooperation between Senegal and Mali, a Joint Standing Committee was set up with administrative focal points for monitoring child trafficking. But as neither country has arranged for the financial and human resources to translate commitments into action, this Committee is not functional and no meetings of the focal points have been held.

\subsection{Conclusion}

Knowledge about the situation of girls who guide beggars is sparse. The insights obtained from this research underscore the importance of recognizing the 
presence of these girls among the population of children and young people who move across borders. The fact that most of them were persuaded to leave their biological family and their village and cross the Senegal-Mali border to carry out such strenuous activity proves they are not only victims. Although their agency is circumscribed by the relationships that organize their migration, they can be agents having unique personhood. They face major constraints in achieving personal well-being and in maintaining personal security with regard to health, housing, and income.

In this respect, the view that children's rights programmes should have an approach that is person-centred (White 2002) rather than one merely categorycentred (based on an identity arbitrarily fixed by gender or a given age limit) seems to make sense. The multiple forms of vulnerability faced by girls who guide beggars suggest that in their situation, many structural inequalities have been reinforced and/or produced. Micro-processes of social transformation that are gendered and generation-based are such that the normative distinction between the categories of 'migration' and 'trafficking', 'childhood' and 'adulthood', 'ability' and 'disability' may not always be appropriate. Improvement of this knowledge should be a priority for researchers.

Understanding the reality of begging communities from the perspective of multiple conditions of disabil- ity and vulnerability may open up new avenues for research and action. Viewing adults and children as two fixed categories can constrain an understanding of the multiple relations amongst, and between, adults and children, and the changing nature of power that underpins these relationships in matters of both mutual interest and resistance (White 2002). Studying children in relation to migratory processes must go beyond viewing them as only passive extensions of adult actors to ensure a better understanding of their being active agents in their own efforts and imaginaries of the world in relation to the varying circumstances under which they migrate. This has implications for legal as well as policy practices.

Finally, given the context of a multidimensional crisis (economic, social, and environmental) facing West Africa and the relatively lucrative benefits of migration for begging as a livelihood, the migration of children and young people in this context is unlikely to stop unless sustainable alternatives for the blind can be found. Only a bold policy aimed at greater social justice that also gives a cognitive dimension to the quotidian aspects of human security as intergenerational mutual dependence generally and in communities affected by river blindness could change this situation. A new prism on social justice is needed to help overcome the tendency to disaggregate social problems into discrete challenges facing specific groups rather than to define them as being interrelated.

\section{Appendix: Legal and Institutional Frameworks to Combat Child Trafficking relevant to Mali and Senegal}

\section{International Instruments}

11. Convention against Transnational Organized Crime and its Protocol to Prevent, Suppress and Punish Trafficking in Persons, Especially Women and Children

12. Convention on the Rights of the Child, adopted by the General Assembly in its resolution 44/25 of 20 November 1989, United Nations, Treaty Series, vol. 1577, no. 2753I.

13. Optional Protocol to the Convention on the Rights of the Child on the sale of children, child prostitution and child pornography, adopted by the General Assembly in its resolution 54/263 (annexe II) of 25 May 2000, United Nations, Treaty Series, vol. 2I7I, no. 2753I.

14. Convention concerning Forced or Compulsory Labour, I930 (Convention No. 29), of the International Labour Organization Convention, United Nations, Treaty Series, vol. 39, no. 6r2.

15. ILO Convention 182óThe Worst Forms of Child Labour Convention, adopted in I999 and ratified by I73 nations by 20IO. Article 2 defines a child as someone under the age of I8.

16. Convention on the Elimination of All Forms of Discrimination against Women, adopted by the General Assembly in its resolution 34/I80 of I8 December 1979 (article 6 refers to traffic in women and exploitation of prostitution of women), United Nations, Treaty Series, vol. I249, no. 20378

\section{Regional Instruments}

1. The African Charter on the Rights and Welfare of the Child entered into force on 29 November 1999. Article 29 of this Charter states that States parties shall take appropriate measures to prevent: (a) the abduction, the 
sale of, or trafficking of children for any purpose or in any form, by any person, including parents or legal guardians of the child; (b) the use of children in all forms of begging.

2. The African Charter on the Rights and Welfare of the Child that came into force on 29 November I999.

3. The Protocol to the African Charter on Human and Peoplesí Rights on the Rights of Women, adopted in Maputo in 2003.

4. Economic Community of West African Statesí Declaration on the Fight against Trafficking in Persons (the twenty-fifth Ordinary Session of Authority of Heads of State, held in Dakar on 20-2I December 200I, with a Plan of Action against Trafficking in Persons (2002-2003) annexed to the Declaration.

\section{Bilateral Agreement}

A bilateral agreement on the struggle against trafficking and trafficking of children signed between Senegal and Mali, 22 July 2004 in Dakar.

\section{References}

Adepoju, Aderanti, 2004: "Trends in international migration in and from Africa", in: Massey, Doris. S. and Taylor, J. Edward (Eds.): International Migration Prospects and Policies in a Global Market (Oxford: Oxford University Press): 59-I03.

Adepoju, Aderanti, 2005: "Review of Research and Data on Human Trafficking in sub-Saharan Africa”, in: International Migration, 43,I-2: 75-98.

Awumbila, Mariama; Ardayfio-Schandorf, Elizabeth, 2008: "Gendered poverty, migration and livelihood strategies of female porters in Accra, Ghana”, in: Norwegian Journal of Geography, 62,3: I7I-I79.

Bâ, Cheikh, Oumar, 1996: "Migrations régionales et relations de genre dans la vallée du fleuve Sénégal”, in: Africa Development, 23,3: 95-II9.

BIT/LUTRENA, 2007: Etude sur la traite des enfants au Mali: Dimensions internes, phénomènes transfrontaliers, rôle et responsabilités du secteur privé. Rapport final (Dakar: Bureau International du Travail (BIT)/Programme de Lutte Contre La Traite des Enfants a des Fins d' Exploitation de leur Travail en Afrique de l'Ouest et du Centre (LUTRENA)).

Brockerhoff, Martin; Eu, Hongsook, I993: "Demographic and Socioeconomic Determinants of Female Rural to Urban Migration in Sub-Saharan Africa", in: International Migration Review, 27,3: 557-577.

Bop, Codou; Cissé, Fanta; Touré, Aissa; Niang, Cheikh Ibrahima, 20I2: Femmes, Migration et Droits au Mali (Dakar: Centre de Recherches pour le Développement International (CRDI) Groupe de Reserche sur les Femmes et Lois au Senegal (GREFELS)).

Bocquier, Philippe; Traoré, Sadio, 2000: Urbanisation et dynamique migratoire en Afrique de l'ouest: la croissance urbaine en panne (Paris: L'Harmattan).

Bourgeot, André, 1977: "Observations critiques sur "Les Migrations africaines”, in: L'Homme, I7,2-3: II7-I23.

Busza, Joanna; Castle, Sarah; Diarra, Aisse, 2004:"Trafficking and Health", in: British Medical Journal, 328: I369-I37I.
Clark-Kazaka, Christina Rose, 2009: “Towards a Working Definition and Application of Social Age in International Development Studies", in: The Journal of Development Studies, 45,8: I307-I324.

Colvin Lucie, Editor, 1981: The Uprooted of the Western Sahel: Migrants' Quest for Cash in Senegambia (New York: Praeger Publishers).

Cordell, Dennis D.; Gregory, Joel W.; PicheÏ, Victor, I996: Hoe and wage: A social history of a circular migration system in West Africa (Boulder: Westview Press).

David, Phillipe, I980: Les navétanes. Histoire des migrants saisonniers de l'arachide en Sénégambie des origines à nos jours (Dakar: Nouvelles Editions Africaines (NEA)).

De Haan, Arjan; Brock, Karen; Coulibaly, Ngolo, 2002: "Migration, Livelihoods and Institutions: Contrasting Patterns of Migration in Mali”, in: Journal of Development Studies, 38,5: 37-58.

De Lange, Albertine, 2007: "Child labour migration and trafficking in rural Burkina Faso", in: International Migration, 45,2: I47-I67.

Diop, Momar Coumba 2008: Le Sénégal des Migrations, Mobilités, Identités et Sociétés (Paris: Khartala).

Eshia, Owusuaa, 2010: Streetism: The Lived Experiences of Unaccompanied Migrant Children and their right (Master Thesis in Philosophy in Childhood Studies, Norwegian University of Science and Technology Faculty of Social Studies and Technology Management Norwegian Centre for Child Research, Trondheim).

Fall, Papa Demba, 2003: Migration internationale et droits des travailleurs au Sénégal, SHS/2003/MC/5 (Paris: UNESCO).

Findley, Sally, I989: "Les migrations feminines dans les villes africaines: une revue de leurs motivations et experiences", in: Philippe, Antoine; Coulibaly, Sidiki (Eds.): L'insertion urbaine des migrants en Afrique. (Paris: ORSTOM).

Findley, Sally E., I99I: "Sécheresse et migration dans la vallée du fleuve Sénégal .Les femmes et les enfants dominent le nouveau type du migrant", in: Pop Sahel, i6 (April): 19-28. 
Findley, Sally E. 1997: "Migration and family interactions in Africa”, in: Aderanti, Adepoju (Ed.): Family, population and development (London: Zed Books): Io9-I38.

Foltz, William J., I965: From French West Africa to the Mali Federation (New Haven CN: Yale University Press).

Hashim, Iman; Thorsen, Dorte, 20II: Child Migration in Africa (New York: Zed Books).

Gondola, Charles Didier, I997a: "Unies pour le meilleur et pour le pire - Femmes africaines et villes coloniales: une histoire du métissage", in: Cli-Histoire, femmes et societies, 6: 87-IO4.

Gondola, Charles Didier, I997b: Villes Miroirs: Migrations et identités urbaines à Kinshasa et Brazzaville I930-1970 (Paris: Editions L'Harmattan).

Gubert, Flore, 2007: "Migration and Development: Mixed evidence from western Mali”, in: Development, 50,4: 94-Ioo.

Kaplan-Myrth, Nili, 200I: "Blindness Prevention in Mali: Are Improvements in Sight?", in: Disability Studies Quarterly, 2I,3: 9I-IO3.

Kielland, Anne; Tovo, Maurizia, 2006: Children at Work: Child Labor Practices in Africa (Boulder, CO: Lynne Rienner Publishers).

Labouret, Henri, 1929; "La Parenté à Plaisanteries en Afrique Occidentale", in: Africa: Journal of the International African Institute, 2,3: 244-254.

Lambert, Michael, 2007: "Politics, patriarchy, and the new traditions: understanding female migration among the Jola (Senegal, West Africa)”, in: Hahn, Hans P.; Klute, George (Eds): Cultures of Migration: African Perspectives (Berlin: Lit Verlag): I29-I46.

Lesclingand, Marie, 2004: "Nouvelles stratégies migratoires des jeunes femmes rurales au Mali: de la valorisation individuelle à une reconnaissance sociale”, in: Sociétés contemporaines, 55: 2I-42.

ILO, 2007: Combating the trafficking of children for labour exploitation in West and Central Africa (Geneva: International Labour Organization (ILO)/ International Programme on the Elimination of Child Labour (IPEC)).

Machel, Graça, 1996: The Impact of Armed Conflict on Children (New York: United Nations).

Moens, Bruno; Zeitlin, Veronica; Bop, Codou; Gaye, Rokhaya, 2004: A Study of the Practice of Trafficking in Persons in Senegal, A Report (Dakar: United States of Agency for International Development (USAID)).

Mufioz, Beatriz; West, Sheila, 1997: "Trachoma: The Forgotten Cause of Blindness", in: Epidemiologic Reviews, I9,2: 205-2I7.

Ndiaye, Amadou, 20I2: "Agricultural Non-family Workers (Sourga) in Senegal River Valley", Paper presented at an international conference on the future of the agrifood sector in Africa: Young People, Farming and Food, I9-2I March, 2OI2, Accra, Ghana, co-hosted by the Future Agricultures Consortium and the Institute of Statistical Social and Economic Research (ISSER), University of Ghana.

Ndiaye, Ababacar, 2009: La traite et le trafic des filles entre le Mali et le Sénégal: Analyse juridique de la situation des filles guides de mendiants et domestiques au Sénégal au regard de l'Accord de coopération, de la loi et des instruments juridiques, (Dakar: Groupe de researche sur les femmes et Lois au Senegal (GREFELS)).

Remme, J. F. H. 1995: "The African Programme for Onchocerciasis Control: Preparing to Launch", in: Parasitiology Today, I,II: 403-406.

Riddell, J., Barry, I980 "Is Continuing Urbanization Possible in West Africa?", in: African Studies Review, 23,1: 69-79.

Schrage, Elliot J.; Ewing, Anthony P., 2005, "The Cocoa Industry and Child Labour", in: The Journal of Corporate Citizenship, I8 (Summer): 99-II2.

Serra, Renata, 2009: "Child fostering in Africa: When labor and schooling motives may coexist", in: Journal of Development Economics, 88,I: 157-I70.

Sommer, Alfred, I989: "Organizing to Prevent Third World Blindness"”, in: American Journal of Ophthalmology, IO7,5: 544-546.

Sy, Maimouna, I99I: "Les migrations féminines selon les ethnies du Sénégal” communication à la Conférence: Femme, Famille et Population (Ouagadougou: Burkina Faso Union Africaine pour l'Etude de la Population).

Thylefors, Bjorn, 1985: "Development of Trachoma Control Programs and the Involvement of National Resources", in: Reviews of Infectious Disease, 7,6: 774-776.

Toulmin, Camilla; Guèye, Bara, 2003: Transformations in West African agriculture and the role of family farms (London: International Institute for Environment and Development (IIED).

Truong, Thanh-Dam, 2005: Poverty, Gender and Human Trafficking: Rethinking Best Practices in Migration Management (Paris: United Nations Educational, Scientific and Cultural Organization (UNESCO).

Truong, Thanh-Dam, 2006: "Governance and poverty in sub-Saharan Africa: rethinking best practices in migration management", in: International Social Science Journal; 58,190: 697-7I4.

UNICEF, 2002: Child Trafficking in West Africa: Policy Responses (Florence: Innocenti Research Centre, United Nations Children's Fund).

UNICEF; UCW, 2009: Comprendre le travail des enfants au Mali: Rapport sur le travail des enfants (Rome: Understanding Children Work (UCW), United Nations Children's Fund (UNICEF).

UNODC, 2008: Toolkit to Combat Trafficking in Persons Global Programme against Trafficking in Human Beings (Vienna: United Nations Office on Drugs and Crime (UNODC)).

White, Sarah, 2002: "Being, becoming and relationship: conceptual challenges of a child rights approach in development", in: Journal of International Development, I4, 8: I095-IIO4.

Yen, Iris, 2008: "Of vice and men: A new approach ro eradicating sex trafficking by reducing male demand through educational programs and abolitionist legislation”, in: Journal of Criminal Law and Criminology, 98,2: 653686.

Open Access. This chapter is distributed under the terms of the Creative Commons Attribution Non-commercial License, which permits any noncommercial use, distribution, and reproduction in any medium, provided the original author(s) and source are credited. 